\title{
Eccrine Poroma of the Auricle: A Case Report
}

\author{
Tae Hoon Kong ${ }^{1}$, Tae Hyoung Ha ${ }^{1}$, Min Seob Eom², and Sang Yoo Park ${ }^{1}$ \\ ${ }^{1}$ Departments of Otolaryngology-Head and Neck Surgery, ${ }^{2}$ Pathology, Yonsei University Wonju College of Medicine, Wonju, Korea
}

\author{
Received June 20, 2014 \\ Revised September 13, 2014 \\ Accepted October 23, 2014 \\ Address for correspondence \\ Sang Yoo Park, MD, PhD \\ Department of Otolaryngology- \\ Head and Neck Surgery, \\ Yonsei University \\ Wonju College of Medicine, \\ 20 Ilsan-ro, Wonju 220-701, Korea \\ Tel +82-33-741-0642 \\ Fax +82-33-732-8287 \\ E-mail sangyoo3@yonsei.ac.kr
}

\begin{abstract}
Eccrine poroma is described as a benign neoplasm originating from the intraepidermal eccrine duct of sweat glands. This tumor is known to arise in bare skin areas, but more rarely appeared in head and neck region. A 54-year-old female presented with a mass on the retroauricular aspect of the left auricle. There was a soft, protruding, and purple-colored, solitary mass of about $1.0 \times 1.0 \mathrm{~cm}$ in size. After authors performed an excisional biopsy, eccrine poroma was confirmed histopathologically. Thus, we report a rare case of eccrine poroma of the ear with the review of literature.

Korean J Audiol 2014;18(3):151-152
\end{abstract}

\section{Introduction}

Eccrine poroma is a benign neoplasm of the sweat glands originating from the intraepidermal eccrine duct. ${ }^{1)}$ This unusual tumor is known to arise in bare skin areas, such as the sole of the foot. Recently it was revealed that it could occur in more various skin region. ${ }^{2)}$ But only few cases have been reported in the head and neck area. We especially report a rare case of eccrine poroma of the ear auricle.

\section{Case Report}

A 54-year-old female presented with a gradually increasing mass on the auricle for one year. On physical examination, there was a soft, protruding, and purple-colored, solitary mass, $1.0 \times$ $1.0 \mathrm{~cm}$ in size on the retroauricular surface of the left auricle (Fig. 1). There was no history of trauma or infection. The patient reported serous discharge but there was no pain nor tenderness. With an impression of an atypical nevus or a melanoma, authors performed an excisional biopsy under local anesthesia. Histopathological findings revealed that broad anastomosing bands extended from the epidermis to dermis with mul-

This is an Open Access article distributed under the terms of the Creative Commons Attribution Non-Commercial License (http://creativecommons. org/licenses/by-nc/3.0/) which permits unrestricted non-commercial use, distribution, and reproduction in any medium, provided the original work is properly cited. tifocal fibrovascular cores and irregular duct-like structures (Fig. 2A). There were also tightly packed small uniform cells with central round to oval nuclei, prominent nucleoli, and occasional clear cytoplasm (Fig. 2B). We did not find any necrosis, nuclear atypia, or mitosis in the specimen. After complete excision, the patient has been followed up without any recurrence for more than 6 months.

\section{Discussion}

Eccrine poroma was first described by Goldman, et al. ${ }^{2)}$ in 1956 as a neoplasm composed of cells that are analogous to cells in the walls of eccrine sweat pores. It is composed of poroid cells and cuticular cells that have much eosinophilic cytoplasm, similar to eccrine ductal cuticles. ${ }^{1)}$ Vacuolizations in the intracytoplasmic and intercellular areas are characteristic histological features, resembling the formation of eccrine ducts. ${ }^{1)}$

This tumor is occurred in bare areas of skin such as the sole of the foot. Goldman, et al. ${ }^{2)}$ reported that the most common sites were soles of feet $(65 \%)$ followed by the hands $(10 \%)$. It rarely occurs in the head and neck area. Only one case of the ear (external auditory canal) has been previously reported, and only three cases reported in the postauricular scalp skin, not on the auricle worldwide. Among seven cases reported in the Korean literature, the scalp was the most common site. ${ }^{3-6)}$

Moore, et al. ${ }^{7)}$ compared patients with poroma in the head 


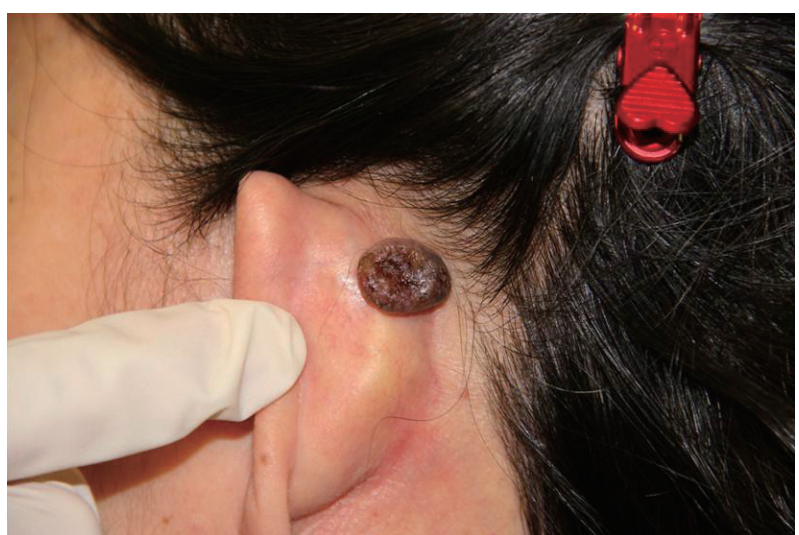

Fig. 1. A soft, protruding, purple-colored, solitary mass with about $1.0 \times 1.0 \mathrm{~cm}$ in size, on the retroauricular surface of the left auricle.
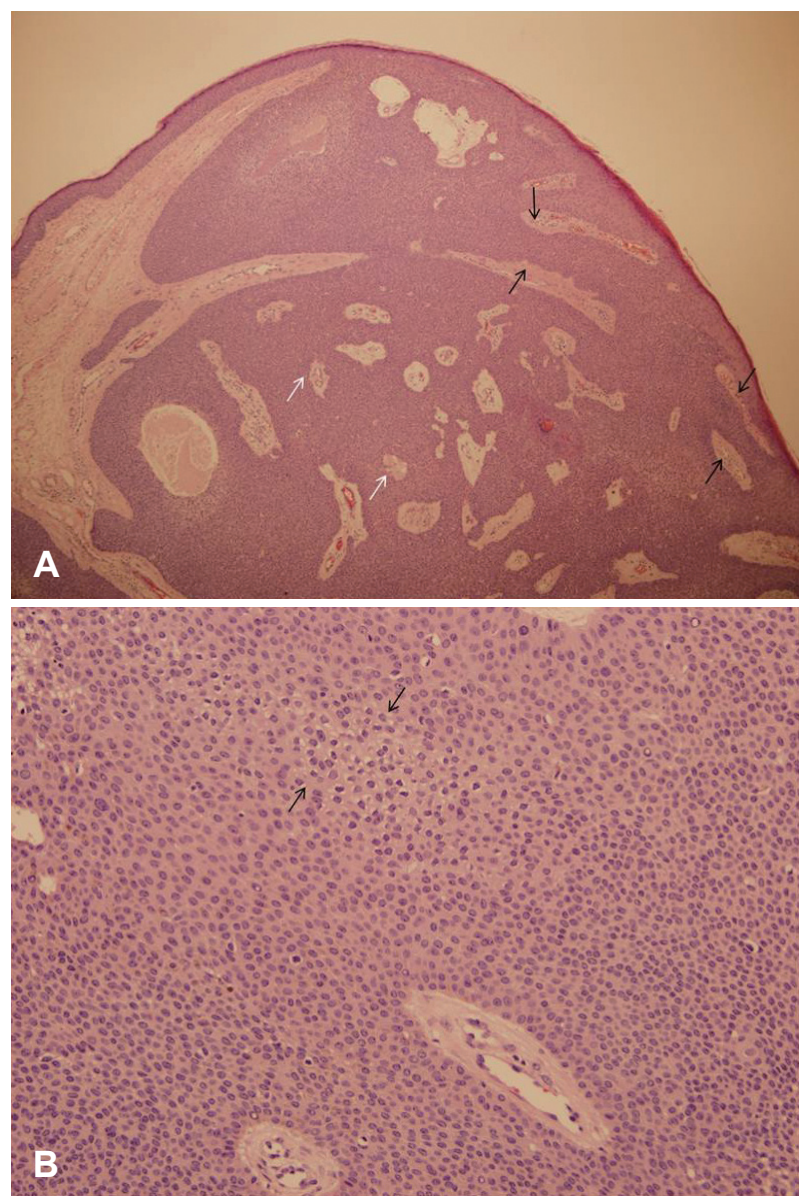

Fig. 2. A: On the low power microscopic view, the tumor revealed broad anastomosing bands (white arrows) extending from epidermis to dermis with multifocal fibrovascular cores (black arrows) and irregular duct-like structures $(\mathrm{H} \& \mathrm{E}, \times 40)$. B: On the high power microscopic view, the tumor cells composed of tightly packed small uniform cells with central round to oval nuclei, prominent nucleoli, and occasional clear cytoplasm. Vacuolizations (arrows) in the intracytoplasmic and intercellular areas are characteristic histological features $(H \& E, \times 200)$ and neck area with lesions occurred in extremities. Lesions of the head and neck were mostly asymptomatic mass, but some patients with poroma in the extremities complained symptoms such as pain or discharge. And more pigmented lesions were noted in the head and neck, compared with mass of the extremities. In our case, the tumor showed a pigmented mass with accompanying discharge but there was no pain.

Histopathological diagnosis is crucial because eccrine poroma should be differentiated from basal cell carcinoma and seborrheic keratosis. ${ }^{3)}$ Poroma seems to have more organoid appearance than basal cell carcinoma. Also, poroma has fewer epithelial cells compared to the seborrheic keratosis of the sweat duct.

Eccrine poroma have a chance to develop 'malignant' poroma (porocarcinoma). It has been found that about $18 \%$ of poromas transform to procarcinoma. ${ }^{8)}$ In a case of reported malignancy, it causes multiple cutaneous metastases leading to death. Porocarcinoma shows more exphytic and ulcerative appearance than eccrine poroma. When the eccrine poroma develop into malignancy, it shows spontaneous bleeding, ulceration, sudden itching sense or pain, and rapid growth in a short period. ${ }^{8)}$ So early detection, complete excision and close follow up are important in the management of the tumor.

\section{REFERENCES}

1) Abenoza P, Ackerman AB. Neoplasms with eccrine differentiation. Philadelphia: Lea \& Febiger;1990.

2) Goldman P, Pinkus H, Rogin JR. Eccrine poroma; tumors exhibiting features of the epidermal sweat duct unit. AMA Arch Derm 1956;74: 511-21.

3) Choi YJ, Kim HS, Lee JY, Kim HO, Park YM. Eccrine poroma on the postauricular area: a rare presentation. Ann Dermatol 2013;25: 92-4.

4) Harada T, Miyamoto T, Takahashi M, Tsutsumi Y. Eccrine poroma in the external auditory canal. Otolaryngol Head Neck Surg 2003; 128:439-40.

5) Kim TJ, Ji HR, Chyung EJ, Park SY, Yang SK, Kim JT. Eccrine poroma: an unusual variant. Korean J Dermatol 1983;21:119-23.

6) Joshi RR, Nepal A, Ghimire A, Karki S. Eccrine poroma in neck of a child--a rare presentation. Nepal Med Coll J 2009;11:73-4.

7) Moore TO, Orman HL, Orman SK, Helm KF. Poromas of the head and neck. J Am Acad Dermatol 2001;44:48-52.

8) Sawaya JL, Khachemoune A. Poroma: a review of eccrine, apocrine, and malignant forms. Int J Dermatol 2014;53:1053-61. 